\title{
Evaluation of passive integrated transponder (PIT) tags in studies of sea urchins: caution advised
}

\author{
Jean-Sébastien Lauzon-Guay ${ }^{1,2, *}$, Robert E. Scheibling ${ }^{1}$ \\ ${ }^{1}$ Department of Biology, Dalhousie University, Halifax, Nova Scotia B3H 4J1, Canada \\ ${ }^{2}$ Present address: School of Zoology, University of Tasmania, Private Bag 5, Hobart, Tasmania 7001, Australia
}

\begin{abstract}
We evaluated the effect of passive integrated transponder (PIT) tags on feeding, growth, movement and survival of the sea urchin Strongylocentrotus droebachiensis in field and laboratory experiments. In cages supplied with kelp, $80 \%$ of urchins $(n=74)$ retained their tag during an $80 \mathrm{~d}$ field experiment. At the end of the experiment, tagged individuals had a lower growth rate (by $42 \%$ ), lower gonad index (by $23 \%$ ), lower survival rate (by $30 \%$ ), and took longer to right themselves (by $30 \%$ ) than untagged control urchins. In a $24 \mathrm{~h}$ feeding experiment in the field, the consumption rate of kelp was lower for tagged urchins (by $67 \%$ ) than for untagged controls. In release and recapture experiments in the field, tagged urchins moved shorter distances over $2.5 \mathrm{~h}$ (by $30 \%$ ) than controls. Although PIT tagging had a detrimental effect on all measures of sea urchin performance, activity and survival in the field, there was no detectable effect of PIT tagging on urchin feeding rate or survival in a $10 \mathrm{wk}$ laboratory experiment. Our results suggest that natural stressors, such as wave action, may limit the utility of PIT tags in field studies of urchins.
\end{abstract}

KEY WORDS: Feeding · Growth - Movement - Survival · Passive integrated transponder tags · Reproduction · Strongylocentrotus droebachiensis · Sea urchins

\section{INTRODUCTION}

Various techniques have been used to tag individual animals for the purpose of tracking movement and habitat use, studying behaviour and recording physiological performance and survival. These tags may be internal or external and generally are adapted to the species and the measurement variables in question. An important criterion for the efficacy of any tag is that it does not adversely affect tagged individuals, and thus bias the measurements obtained from them. This becomes increasingly more challenging for species or individuals of small body size. Since the mid-1980s, the use of passive integrated transponder (PIT) tags has grown rapidly. In a recent review, Gibbons \& Andrews (2004) have documented the use of PIT tags in a broad range of taxa (fish, mammals, birds, reptiles, amphibians and some invertebrates) and ecological applications (behav- ioural studies, physiology, conservation and management, and commercial harvesting).

Producing a long-lasting external tag for sea urchins has proven difficult, and internal chemical tags (e.g. tetracycline and calcein) do not permit individual identification (Hagen 1996, Duggan \& Miller 2001, Dumont et al. 2006). Laboratory studies have demonstrated the potential of PIT tags in measuring growth and survival, without detectable adverse effects, in 2 species of sea urchin: Strongylocentrotus droebachiensis (Hagen 1996) and Evechinus chloroticus (Woods \& James 2005). However, the use of PIT tags in field studies has largely been tempered by the lack of underwater readers (Duggan \& Miller 2001), and is limited to 2 studies of growth and age determination (RogersBennett et al. 2003, Shelton et al. 2006). Recently, the development of smaller and more independent readers, which can be encased in a waterproof housing, has permitted their usage underwater. In the present 
study, we employ such a reader to experimentally investigate the effect of PIT tagging on the movement, feeding rate, growth and survival of sea urchins $S$. droebachiensis in the field, and to compare these to laboratory measures.

\section{MATERIALS AND METHODS}

Growth, reproduction and survival in the field. To test the effect of PIT tags on the survival and growth of Strongylocentrotus droebachiensis in the field, we maintained urchins in cages in an urchin barren at $12 \mathrm{~m}$ depth for $80 \mathrm{~d}$ (20 June to 8 September 2007) at Splitnose Point, Nova Scotia, Canada (for a detailed site description see Lauzon-Guay \& Scheibling 2007a). The square cages $(60 \times 60 \times 25 \mathrm{~cm})$ were constructed of plastic-coated mesh $(2.5 \times 1.0 \mathrm{~cm}$ aperture) . A cement patio stone $(60$ $\times 60 \times 5 \mathrm{~cm}$ ) placed on the bottom of a cage provided both stability and a substrate to which urchins could attach. Lengths of heavy chain $(18 \mathrm{~m}$ long, $2 \mathrm{~cm}$ link diameter) were used to lash together a linear array of 6 cages with $0.5 \mathrm{~m}$ gaps between adjacent cages. There was no displacement of the cages on the seabed during the experiment. The top of each cage was hinged to allow removal of urchins and addition of kelp. At the start of the experiment, large adult urchins ( 40 to $50 \mathrm{~mm}$ test diameter) were collected from the barrens around the cages and brought on board our research vessel. A total of 240 were measured (test diameter, $0.5 \mathrm{~mm}$ accuracy) and injected (through the peristome using a 21 gauge needle) with $0.2 \mathrm{ml}$ of tetracycline $\left(0.01 \mathrm{~g} \mathrm{ml}^{-1}\right)$, a chemical marker used to measure skeletal growth (Kobayashi \& Taki 1969). Of these, 120 were selected haphazardly to receive a PIT tag (TX1411SST, $2.07 \times$ $12.50 \mathrm{~mm}, 132.2 \mathrm{kHz}, 0.102 \mathrm{~g}$, Biomark) also injected through the peristome using a 12 gauge implanter (MK7, Biomark). The tagged and untagged (control) urchins were divided into 3 groups of 40 for each treatment, which were randomly placed in the cages.

The caged urchins were fed 4 to 5 large thalli of kelp Laminaria longicruris at 1 to $3 \mathrm{wk}$ intervals during the experiment. Some kelp remained in each cage at each feeding date, suggesting that urchins were not food limited. Mortality and tag retention were recorded on 4 dates (25 June, 9 July, 10 August, 8 September 2007). On each date, urchins were individually removed from the cages and scanned for the presence of PIT tags using an underwater antenna connected to a reader (Biomark, FS2001F-ISO) in a waterproof housing (Ikelite) (Fig. 1). This system allowed us to check for the presence of the PIT tag without bringing urchins to the surface. Urchins in control cages also were removed during counts to maintain a similar handling effect for control and tagged urchins.
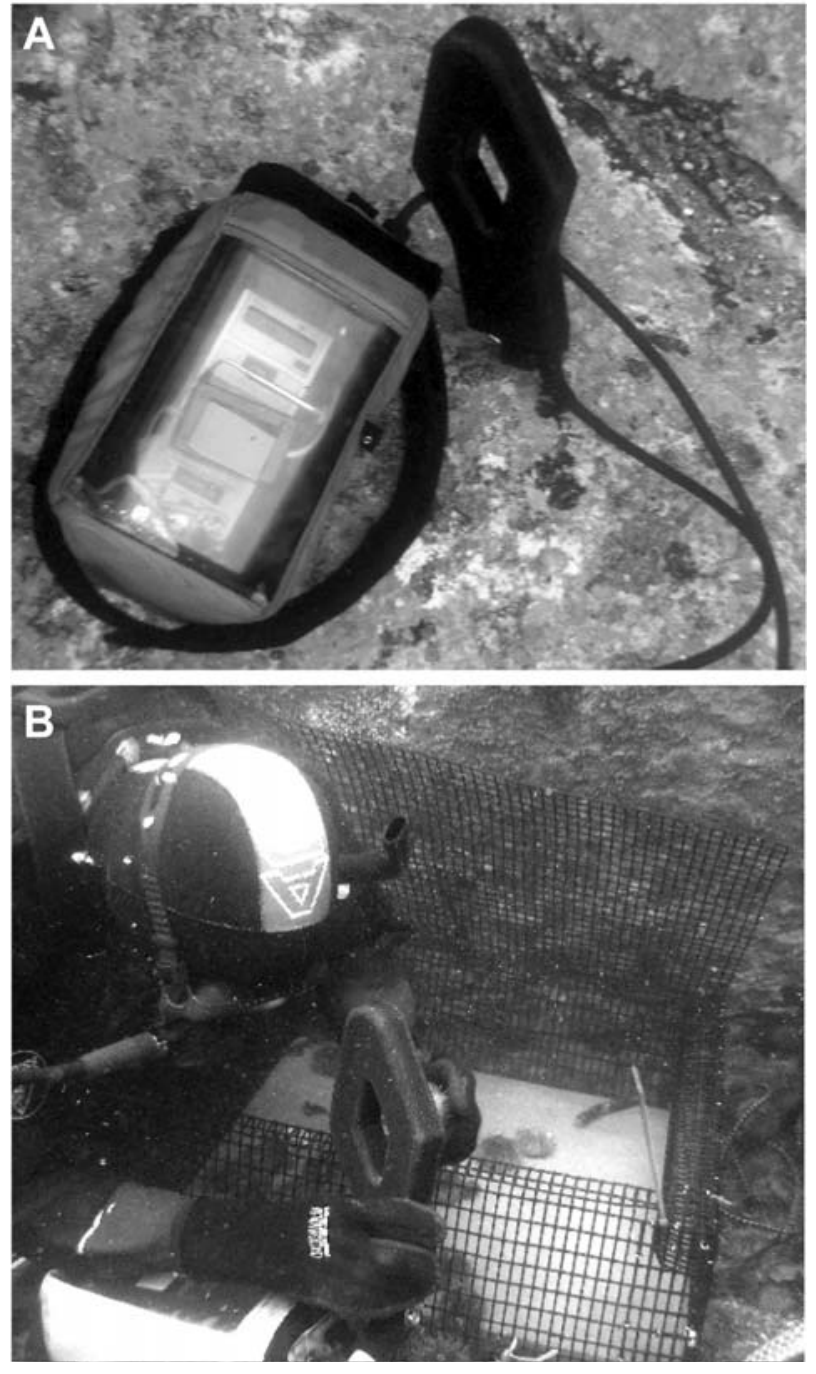

Fig. 1. (A) Underwater passive integrated transponder (PIT)tag reader and antenna. (B) Urchin from the experimental cage being scanned for the presence of PIT tags

At the end of the experiment, all surviving urchins were collected and brought to the laboratory for analysis. The time required for an urchin to right itself after being placed on its aboral side was assessed for a subsample of 18 urchins selected haphazardly from each caged group. All urchins were measured (test diameter, $0.5 \mathrm{~mm}$ accuracy) and weighed (0.001 $\mathrm{g}$ accuracy), and then dissected to excise the gonads, which were also weighed. Gonad index was measured as the weight of the gonads expressed as a percentage of the total body weight. Aristotle's lantern was excised from a subsample of 6 urchins per cage and soaked in 5\% sodium hypochlorite solution overnight to remove organic matter. One of the 10 demi-pyramids was randomly selected from each lantern and growth (as the distance from the tetracycline band to the epiphysis 
junction) was measured under a dissecting stereomicroscope (Nikon, SMK 1500) fitted with an ocular micrometer and illuminated with an ultraviolet (UV) light (UVL-22, Ultraviolet Products).

We compared test diameter, total weight, gonad index, demi-pyramid growth and righting time using a nested ANOVA (analysis of variance) with treatment as a fixed factor (2 levels: PIT tagged or control urchins) and cage as a random factor nested within treatment. When the effect of cage was highly nonsignificant $(p>0.25)$, the nested term was removed from the analysis and treatment was tested over the residual mean square (Winer et al. 1991). Variance was homogeneous in all cases, as determined by Levene's test $(p>0.05)$. Survival was analysed using the proportional hazards regression model (Kalbfleisch \& Prentice 1980), with treatment (PIT tagged or control urchins) and cage (nested within each treatment) as explanatory variables.

Daily average temperature at $12 \mathrm{~m}$ depth, recorded by a temperature logger (Stow-Away TidbiT Temp Logger, Onset Computer Corporation) ranged from 4.5 to $17.8^{\circ} \mathrm{C}$ during the experiment (Fig. 2A). Significant wave height, measured at a meteorological buoy located at the mouth of Halifax Harbour, $11.9 \mathrm{~km}$ from

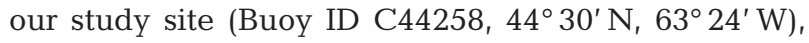
ranged from 0.25 to $2.53 \mathrm{~m}$ (www.meds-sdmm.dfompo.gc.ca) (Fig. 2A). We examined the relationship between urchin mortality in each treatment and average significant wave height and water temperature during sampling intervals using multiple regression to test whether the effects of abiotic conditions on urchins differ between tagged and control animals.

Short-term movement. To test the effect of PIT tags on the movement of urchins, short-term release and recapture trials were conducted on 3 dates ( 8 June, 17 July, 6 October 2007). For each trial, all large urchins (>10 mm diameter) were removed from a circular area of $5 \mathrm{~m}$ radius $\left(78.5 \mathrm{~m}^{2}\right)$ located in the barrens at $12 \mathrm{~m}$ depth. The centre of the cleared area was marked with an eyebolt affixed to the substratum using marine epoxy (Z-Spar A788 Splash zone compound, KopCoat). The experimental area was located $20 \mathrm{~m}$ from the cages and 10 to $20 \mathrm{~m}$ from the kelp bed. No erect algae were present within the area, and the coralline algal-encrusted bedrock was fairly uniform and flat, without large crevices. During each trial, 20 urchins (40 to $50 \mathrm{~mm}$ ) were collected from inside the cleared area, and 10 of those were PIT tagged underwater. Although tagging is more difficult and time consuming underwater when handling implanters with diving gloves, all 10 urchins were tagged in $<5 \mathrm{~min}$. The 20 urchins (10 tagged, 10 untagged controls) were then placed within $10 \mathrm{~cm}$ of the central eyebolt and observed for 2 min to ensure that all individuals had
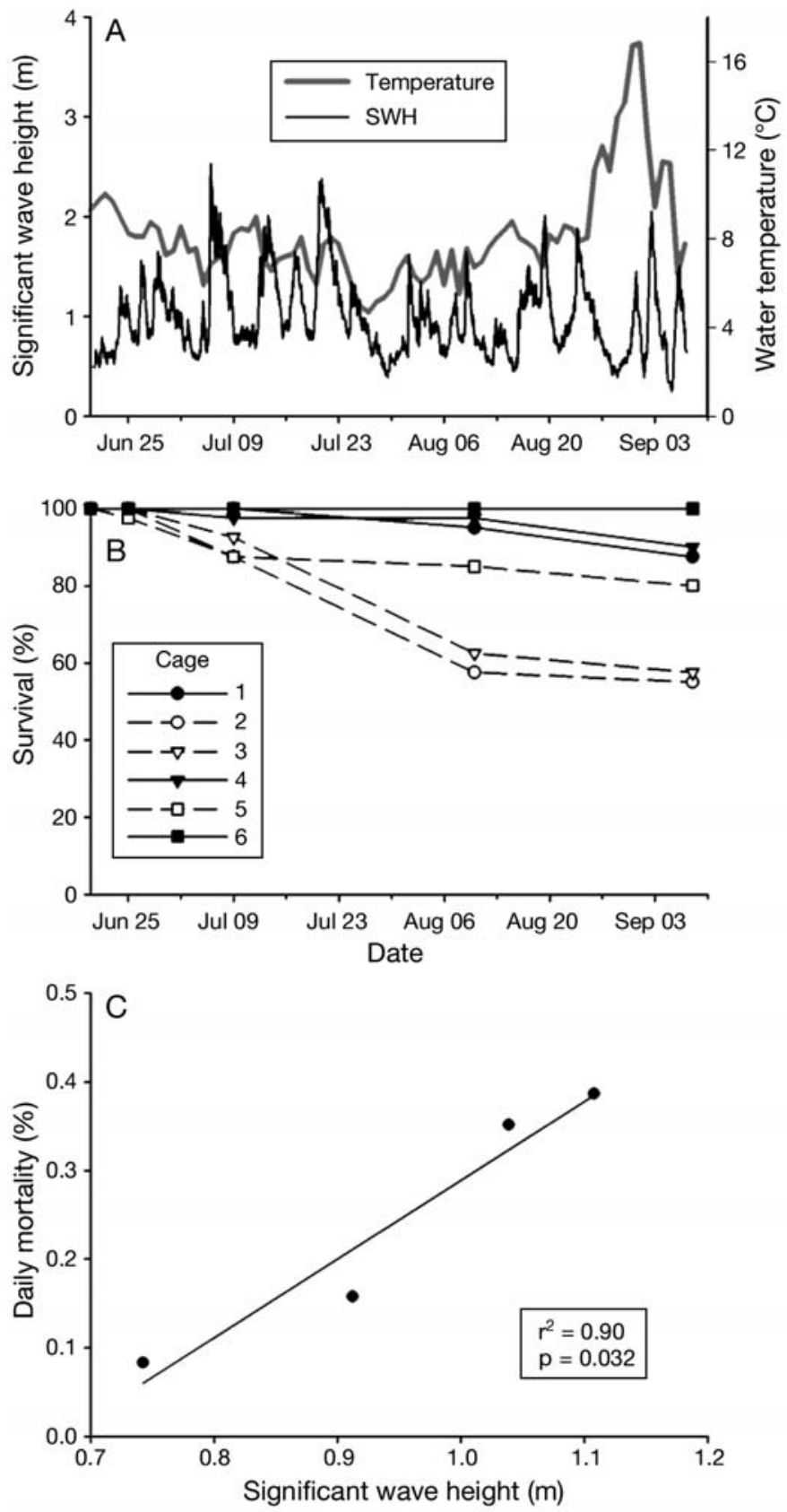

Fig. 2. Strongylocentrotus droebachiensis. (A) Significant wave height from the Halifax Harbour meteorological buoy, water temperature and (B) survival (\%) of sea urchins in 6 cages over $80 \mathrm{~d}$. Filled symbols represent cages with control (untagged urchins) and open symbols represent cages with PIT tagged urchins. (C) Linear regression $(y=0.89 x-0.60)$ of averaged daily mortality (all treatment cages combined) on significant wave height

attached to the substratum. The position of each urchin in relation to the central eyebolt (distance and direction) was measured $2.5 \mathrm{~h}$ after the initial release. A plastic measuring tape attached to the centre eyebolt was used to measure the net displacement $(1 \mathrm{~cm}$ accu- 
racy), and a compass was used to measure the direction of net displacement ( $5^{\circ}$ accuracy). All recovered urchins were scanned for the presence of a PIT tag. Urchins that remained within $10 \mathrm{~cm}$ of the central eyebolt after $2.5 \mathrm{~h}$ were assumed not to have moved. Net displacement was analysed by 2-way ANOVA with treatment as a fixed factor with 2 levels (PIT tagged, control) and trial as a random factor with 3 levels. Departure from a random direction of displacement for each treatment group and trial was measured using Rayleigh's test (Zar 1999). We examined the relationship between urchin movement and significant wave height and water temperature using multiple linear regression (data were log-transformed to meet the assumption of linearity).

Feeding rate in the field. To test the effect of PIT tags on the daily feeding rate of individual urchins in the field, 40 cylindrical plastic containers $(10.8 \mathrm{~cm}$ diameter, $7.8 \mathrm{~cm}$ height) were deployed at $12 \mathrm{~m}$ depth in the barrens, $\sim 50 \mathrm{~m}$ from the cages. Each container was perforated with several $1 \mathrm{~cm}$ diameter holes to allow for water flow, and attached to the substratum using marine epoxy. One day before the start of the experiment, 40 urchins ( 45 to $60 \mathrm{~mm}$ test diameter) were collected from the adjacent barrens and placed individually into containers. Of those, 15 were PIT tagged in situ as per the cage experiment. The urchins were allowed to acclimatise to the containers for $24 \mathrm{~h}$ before the start of the experiment. The next day (6 October 2007), pre-weighed sections of kelp Laminaria longicruris frond (mean \pm SD: $5.13 \pm 1.24 \mathrm{~g}$ ) were individually delivered to the experimental array in sealed bags, and randomly allocated to each container. After $24 \mathrm{~h}$, the containers were collected individually in sealed plastic bags and brought to the surface, where the enclosed urchins were scanned for the presence of a PIT tag. The remaining kelp was returned to the laboratory for weighing. The difference in the weight of kelp (0.001 $\mathrm{g}$ accuracy) provided to and removed from each container was used to measure individual feeding rate. Feeding rates were analysed using an independent-samples $t$-test (Zar 1999).

Feeding rate and survival in the laboratory. To test the effect of PIT tags on the feeding rate of urchins over a 10 wk period, we maintained groups of 30 PIT tagged or control urchins (30 to $40 \mathrm{~mm}$ test diameter) in flow-through $\left(\sim 0.6 \mathrm{l} \mathrm{min}^{-1}\right)$ seawater aquaria $(60 \times 30 \times$ $30 \mathrm{~cm} ; 4 \mathrm{l}$ ), with 2 replicate aquaria for each treatment. Temperature measured at the inflow of the Dalhousie Aquatron system ranged from 5.8 to $10.2^{\circ} \mathrm{C}$ during the experiment. All urchins were injected with tetracycline, and their test diameter was measured at the start of the experiment. Urchins were fed 200 to $400 \mathrm{~g}$ of kelp Laminaria longicruris fronds at weekly intervals throughout the experiment, and residual kelp fragments were removed at each feeding. The difference in the weight of kelp (0.001 $\mathrm{g}$ accuracy) provided to and removed from each aquarium each week was used to calculate the amount consumed per urchin. Due to a flow interruption in 1 tank (Tank 16) on 25 July, which resulted in the death of 10 urchins, we did not include that week in our analysis of feeding rate, and censored those urchins from the survival analysis. Feeding rate was analysed using repeated-measures ANOVA, with treatment (PIT tagged or control) as a fixed factor and tank nested within treatment as a random factor. We used the Huyn-Feldt correction because of a significant departure from sphericity (Mauchly's test, p < 0.05). Survival was compared between tagged and control cages using the proportional hazard model with treatment and tank nested within treatment as explanatory variables.

\section{RESULTS}

\section{Growth, reproduction and survival in the field}

Injection of the PIT tag creates a $2 \mathrm{~mm}$ diameter hole in the peristome that gradually closes over in a few days. When urchins Strongylocentrotus droebachiensis were dissected after $3 \mathrm{mo}$, the tag lay free in the coelomic cavity without tissue growth around it. There was no discernable difference between tagged and control urchins. Surviving individuals in each group retained their spines and normal coloration throughout the experiment, with the exception of a few tagged individuals that exhibited a purple discolouration of the peristome due to the accumulation of red spherule cells around the injection site. Tag retention in the 3 cages was 75,80 and $100 \%$ after $80 \mathrm{~d}$, with the greatest retention in Cage 5, where survival was also greatest ( $80 \%$; Fig. 2B). Most tags ( $\mathrm{n}=12)$ were lost within the first $5 \mathrm{~d}$; none was lost after Day 19.

There was a significant effect of treatment $\left(\chi^{2}=\right.$ 30.79 , $\mathrm{df}=1, \mathrm{p}<0.001)$ and cage nested within treatment $\left(\chi^{2}=12.93, \mathrm{df}=4, \mathrm{p}=0.011\right)$ on urchin survival. A greater percentage of urchins died in cages containing tagged urchins than in control cages (Fig. 2B). By the end of the experiment, survival in control cages was $44 \%$ greater than in cages with tagged urchins. There was a strong positive relationship between the daily mortality rate and the average significant wave height during a sampling interval (Fig. 2C), but water temperature did not enter the regression model.

Average test diameter of urchins in cages ranged from 42.9 to $44.0 \mathrm{~mm}$ at the start of the experiment and did not differ between treatments $\left(F_{1,238}=0.38, \mathrm{p}=\right.$ 0.536) (Fig. 3A). At the end of the experiment, tagged urchins were significantly smaller than controls $\left(F_{1,179}=\right.$ 
4.98, $\mathrm{p}=0.027$ ) (Fig. 3A), resulting in an average growth rate in tagged urchins $\left(0.36 \mathrm{~mm} \mathrm{mo}^{-1}\right)$ that was $42 \%$ of that measured for control urchins $(0.64 \mathrm{~mm}$ $\mathrm{mo}^{-1}$ ). Similarly, the growth of the demi-pyramid in tagged urchins was $42 \%$ of that in controls $\left(F_{1,32}=\right.$ 17.45, p < 0.001) (Fig. 3B). Total body weight at the end of the experiment was also greater in control than tagged urchins $\left(F_{1,179}=6.01, \mathrm{p}=0.0152\right)$ (Fig. 3C) as was the gonad index $\left(F_{1,4}=14.08, \mathrm{p}=0.020\right)$ (Fig. 3D). Tagging also affected the activity level: righting time of tagged urchins (mean \pm SE: $75.0 \pm 4.3$ s) was $30 \%$ longer than that of controls $(57.4 \pm 4.2 \mathrm{~s})$ at the end of the experiment $\left(F_{1,4}=8.68, \mathrm{p}=0.042\right)$.

\section{Short-term movement}

Most urchins (80 to $100 \%$ ) in each trial had moved from the release site after $2.5 \mathrm{~h}$; there was no effect of tagging on the proportion moving in any trial $\left(\chi^{2}=\right.$ $0.05 ; \mathrm{p}=0.821)$. Urchins that had not moved were excluded from subsequent analyses. For those that moved, there was a significant effect of tag $\left(F_{1,47}=\right.$ 4.36, $\mathrm{p}=0.042)$ and trial $\left(F_{2,47}=6.63, \mathrm{p}=0.003\right)$ on the net displacement, but no interaction between these factors $\left(F_{2,45}=0.52, \mathrm{p}=0.599\right)$ (Fig. 4A). On average, control urchins moved $41 \%$ further than
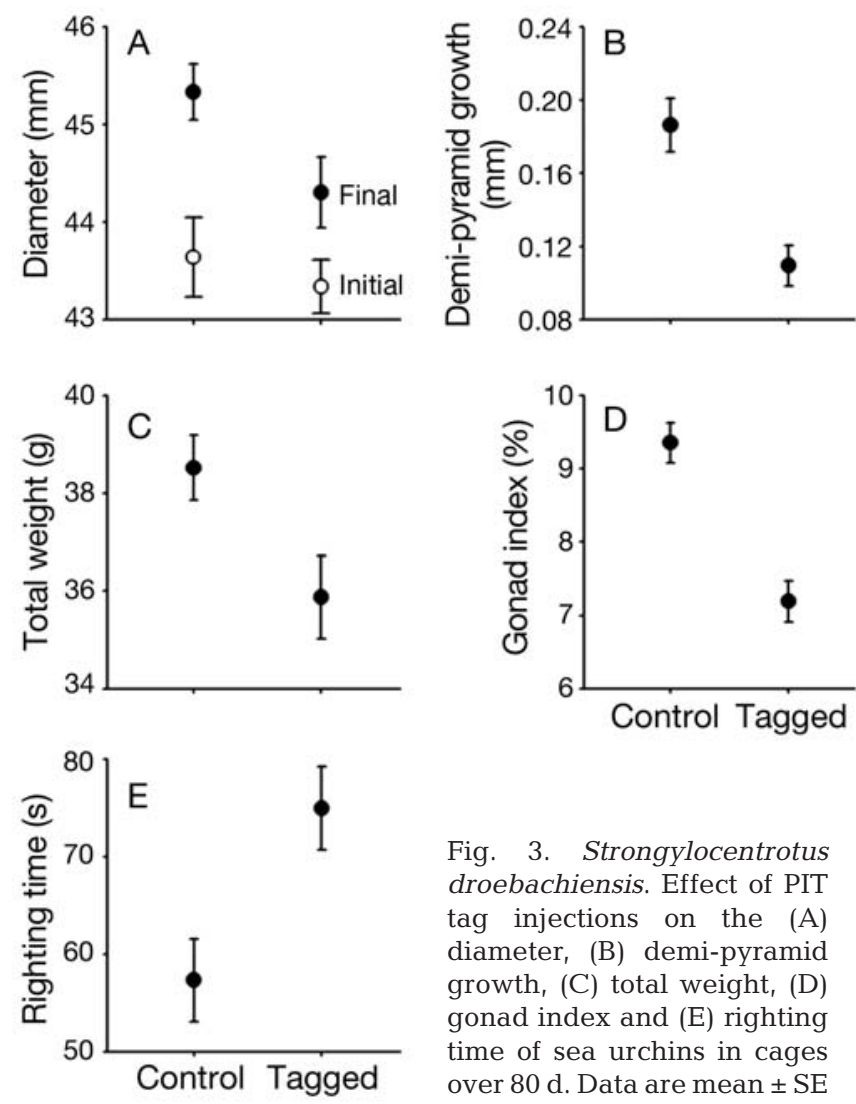

Fig. 3. Strongylocentrotus droebachiensis. Effect of PIT tag injections on the (A) diameter, (B) demi-pyramid growth, (C) total weight, (D) gonad index and (E) righting time of sea urchins in cages over $80 \mathrm{~d}$. Data are mean $\pm \mathrm{SE}$ tagged urchins, and displacement was greater during the third trial than during the first two (Fig. 4A). There was a negative relationship $\left(\mathrm{r}^{2}=0.77, t=\right.$ -3.63, $\mathrm{p}=0.022$ ) between urchin movement and significant wave height during trials, but there was a positive relationship $\left(\mathrm{r}^{2}=0.84, t=4.62, \mathrm{p}=0.010\right)$ between urchin movement and water temperature during trials (Fig. 4C). Both variables explained the same variation in urchin movement, and the regression model became non-significant when both were considered. Direction of movement of control and tagged urchins was not significantly different from random (a uniform distribution of angles) in any trial (Rayleigh's test for uniformity, $\mathrm{p}>0.05$ ).

\section{Feeding rate in the field}

Control urchins consumed significantly more kelp (mean \pm SE: $3.55 \pm 0.18 \mathrm{~g} \mathrm{urchin}^{-1}$ ) than tagged urchins $\left(1.17 \pm 0.27 \mathrm{~g} \mathrm{urchin}^{-1}\right)$ over $24 \mathrm{~h}\left(t_{38}=5.98, \mathrm{p}<0.001\right)$. Two urchins (13\%) lost their tags, and no mortality was observed in either group.

\section{Feeding rate and survival in the laboratory}

Although over the $10 \mathrm{wk}$ experiment, control urchins consumed more kelp (mean \pm SE: $0.89 \pm 0.11 \mathrm{~g} \mathrm{urchin}^{-1}$ $\left.\mathrm{d}^{-1}\right)$ than tagged urchins $\left(0.61 \pm 0.07 \mathrm{~g} \mathrm{urchin}^{-1} \mathrm{~d}^{-1}\right)$, there was no significant effect of treatment $\left(F_{1,2}=9.40\right.$, $\mathrm{p}=0.092$ ) or significant interaction between treatment and time $\left(F_{8,16}=0.52, \mathrm{p}=0.821\right)$ on the feeding rate of urchins in tanks (Fig. 5A). This is likely caused by the high level of variation in feeding rates observed between tanks (Fig. 5A).

There was no effect of treatment $\left(\chi^{2}=2.54, \mathrm{df}=1, \mathrm{p}=\right.$ $0.111)$, but a significant effect of tank within treatment $\left(\chi^{2}=15.01, \mathrm{df}=2, \mathrm{p}<0.001\right)$ on survival of urchins during the experiment. Most of the mortality occurred in Tank 9 (Fig. 5B). Only 5 urchins (8\%) lost their tags, all during the first $2 \mathrm{wk}$ of the experiment.

\section{DISCUSSION}

For a tagging procedure to be effective, there must be a high level of tag retention and a negligible effect of tagging on individual performance, behaviour and survival. In our study with Strongylocentrotus droebachiensis, internally injected PIT tags satisfied the retention criterion (85 and $92 \%$ in field and laboratory experiments, respectively) but had significant negative effects on urchins in the field. A decreased rate of growth (by $42 \%$ ), gonadal production (by $23 \%$ ) and 

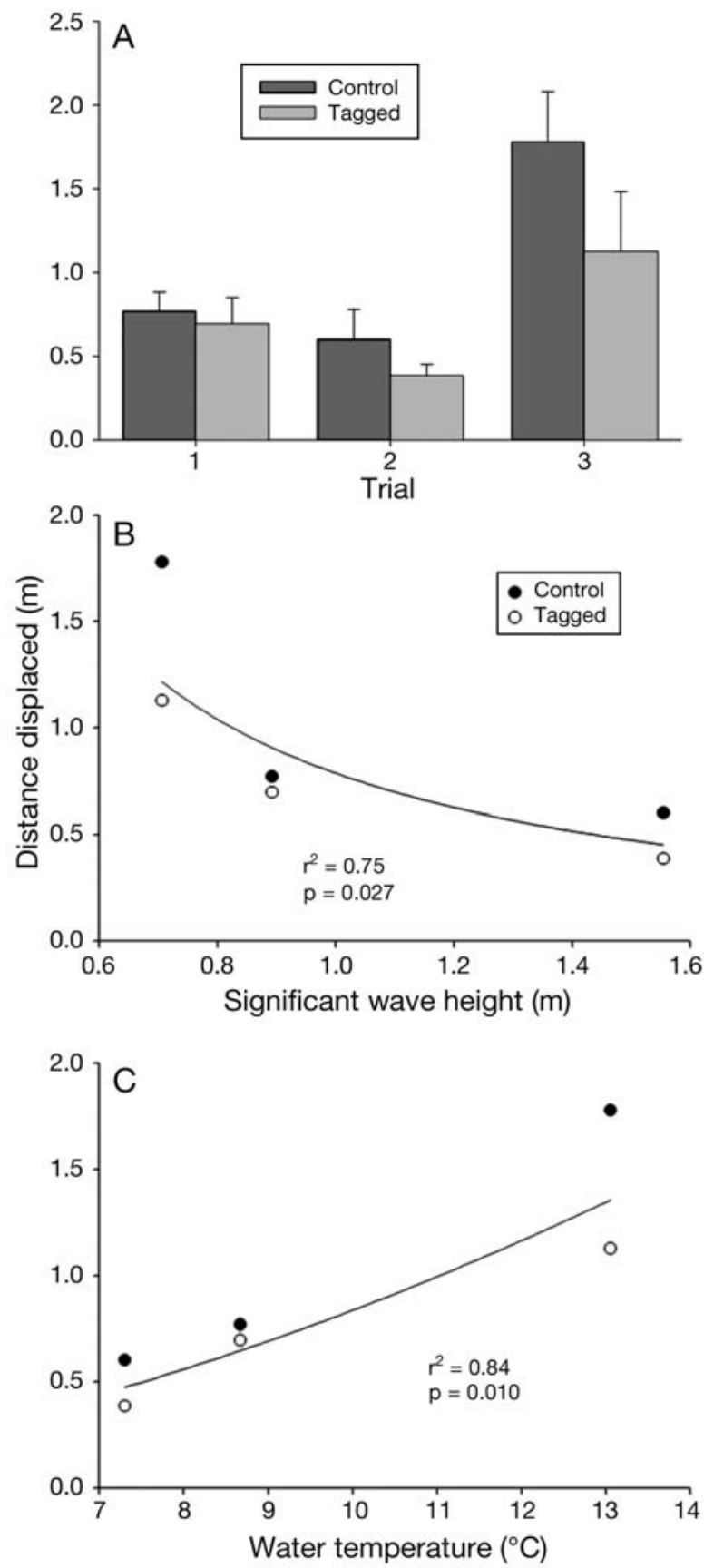

Fig. 4. Strongylocentrotus droebachiensis. (A) Mean + SE distance displaced by control (untagged) and PIT tagged sea urchins over $2.5 \mathrm{~h}$ in 3 movement trials. Relationship between mean distance displaced (for both treatments) and (B) significant wave height recorded at the Halifax Harbour buoy $(y=$ $\left.0.786 x^{-1.25}\right)$ and $(C)$ water temperature recorded at the site $\left(y=0.013 x^{1.81}\right)$ during each trial

survival (by $30 \%$ ) of PIT tagged urchins relative to untagged controls contraindicates usage of PIT tags in studies aimed at measuring these variables in natural populations. Such adverse effects may be related, in part, to an inhibitory effect of PIT tags on the feeding

ability of urchins. In our $24 \mathrm{~h}$ feeding experiment in the field, tagged urchins consumed only one-third the mass of kelp compared to control urchins. This pronounced difference in feeding rate may be attributed to insufficient recovery time after tag injection. However, the amount of kelp remaining in the cages during the $80 \mathrm{~d}$ experiment, although not measured, was consistently greater in cages with tagged urchins than in those with controls, which indicates a lower feeding rate for tagged urchins on a longer term. These results, combined with reduced movement and longer righting times, provide ample evidence of reduced activity associated with PIT tagged urchins in the field. Reduced nutrition also may affect survivorship, especially in concert with other stressors.

In the first study to evaluate the use of PIT tags in Strongylocentrotus droebachiensis in the laboratory, Hagen (1996) did not detect an effect of tagging on growth or survival of urchins over an 18 mo period. We also were unable to detect an effect of tags on survival in our laboratory experiment, as there was greater variability between tanks than between tagged and control treatments. The greatest mortality occurred in a tank containing tagged urchins, and tagged urchins had a lower overall survival rate than control urchins (although this difference was not statistically significant). It is not possible to assess between-tank variation in Hagen's experiment as he only used 1 tank. He also used a relatively small number of urchins (16 ind. treatment ${ }^{-1}$ ), resulting in a low power for statistical tests. Also, control urchins in Hagen's study were, on average, $10 \%$ larger than tagged urchins (mean \pm SE: $44.3 \pm 2.1 \mathrm{~mm}$ vs. $40.4 \pm 2.1 \mathrm{~mm}$ ) at the beginning of the experiment. Because growth of adult urchins decreases with size (Meidel \& Scheibling 1998, Russell et al. 1998), the initial difference in test diameter between groups (although not statistically significant) could have masked a tag effect.

PIT tags also have been used in laboratory studies with 2 other species of sea urchins, Strongylocentrotus franciscanus (Kalvass et al. 1998) and Evechinus chloroticus (Woods \& James 2005), both of which are considerably larger than $S$. droebachiensis. The tags had no detectable effects on growth or survival of $E$. chloroticus (Woods \& James 2005). Results of the study with $S$. franciscanus, which involved 3 different types of tagging procedures, are not as conclusive (Kalvass et al. 1998). Each experimental animal received a coded wire tag, alone or in combination with either a PIT tag or tetracycline injection. Because only 1 tank was used per treatment, it is impossible to differentiate between tag and tank effects. Although Kalvass et al. found an overall effect of treatment (or tank) on growth of urchins after $205 \mathrm{~d}$, they do not specify the betweengroup differences. They also found a significant effect 

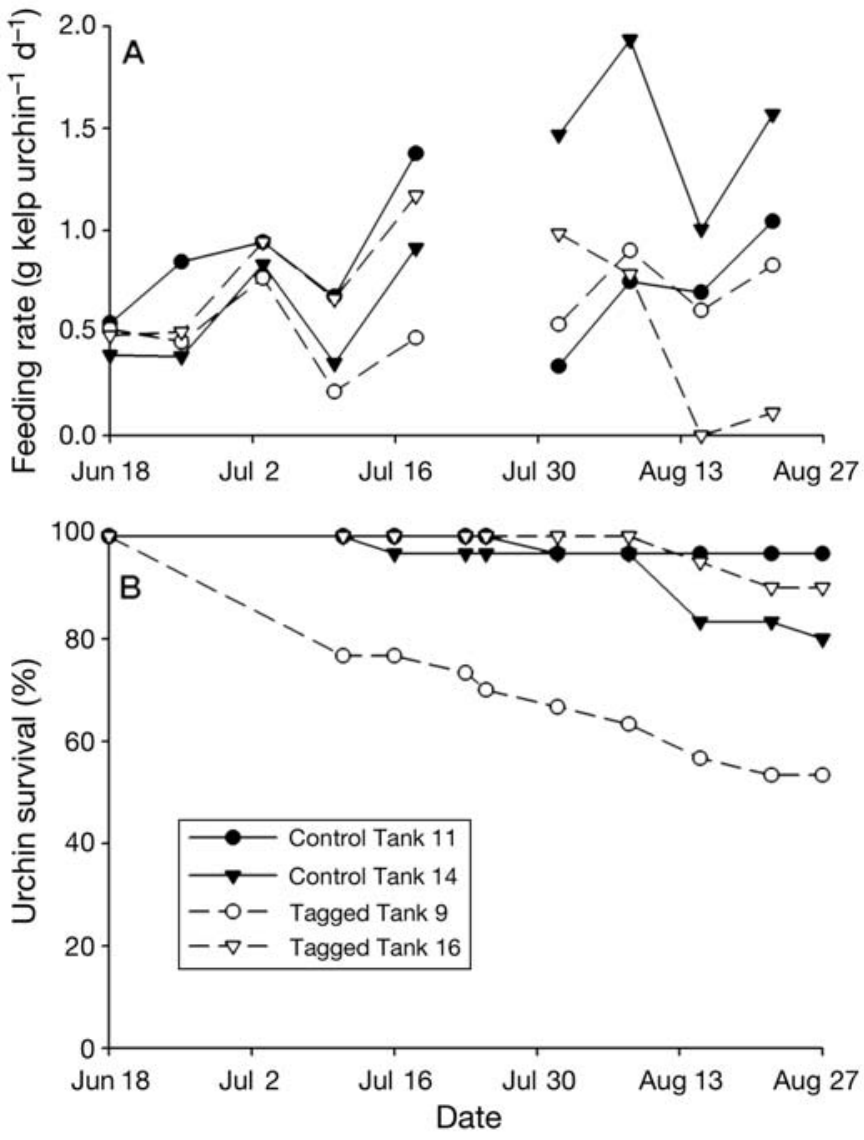

Fig. 5. Strongylocentrotus droebachiensis. (A) Feeding and (B) survival rates of control (untagged) and PIT tagged sea urchins in 4 aquaria

of tag on the shape of urchins (height:diameter ratio), with PIT tagged urchins having a higher ratio than those injected with tetracycline. This suggests a slower growth in test diameter in the PIT tagged group than in the tetracycline group. However, a meaningful conclusion regarding the effect of these various tagging procedures cannot be reached because of the inadequacies of the experimental design and analysis.

Our release and recapture experiment showed that PIT tagging reduced the movement of urchins, although our trials were conducted immediately after tag injection and for only $2.5 \mathrm{~h}$. Further studies to establish long-term effects of PIT tagging on displacement and movement patterns of urchins are needed. We also observed a significant reduction in righting time, an indicator of urchin activity (Percy 1973), in individuals sampled from our experimental cages after 80 d. Urchin movement across trials decreased with significant wave height and increased with water temperature. Because both environmental variables are strongly correlated $(\mathrm{r}=0.89)$, it is not possible to differentiate their relative effects on movement. Strongylocentrotus droebachiensis maintains a high level of activity in cold water (Percy 1973), which decreases as temperature exceeds $17^{\circ} \mathrm{C}$ (Lauzon-Guay \& Scheibling 2007b). In our field trials, however, temperature ranged between 7 and $13^{\circ} \mathrm{C}$, suggesting it had little effect. Wave action, on the other hand, has been shown to have a negative effect on individual movement of urchins in laboratory (Kawamata 1998) and field experiments (Lauzon-Guay \& Scheibling 2007b) and on the rate of advance of urchin feeding fronts (Lauzon-Guay \& Scheibling 2007a,b). Thus, the greater rate of movement in the third trial was likely related to calmer sea conditions.

Wave action also may have influenced survival in our field cages, as most of the mortality occurred during periods of the highest significant wave height. Although the cages did not move during these storm events, the enclosed urchins may have been dislodged and swept against the cage walls, resulting in external tissue damage and increased risk of infection. Water temperature remained fairly constant throughout most of the experiment, but peaked at $17.8^{\circ} \mathrm{C}$ during the last 2 wk. However, these high temperatures only lasted a few days and did not result in increased mortality.

Our study shows the effect of PIT tags on sea urchins can differ between field and laboratory settings, suggesting that environmental variables, such as wave action, water temperature and food availability, play a role in mediating this effect. While PIT tags may have negligible effects on urchins maintained under optimal conditions in the laboratory, environmental stressors may magnify any detrimental effects of injection or retention of PIT tags, and limit the reliability of this tagging procedure in field studies. On this basis, we advise caution in the use of PIT tags in sea urchin research, especially in field studies. Researchers interested in using this technology should insure that the tags are not biasing their measurements, and hence compromising the conclusions they draw from them. Larger urchins may not be as susceptible to the effects of PIT tags, and the development of smaller tags (with a narrower diameter) may eliminate or moderate some of the negative effects of PIT tags on smaller urchins, such as Strongylocentrotus droebachiensis. The use of PIT tags may be extended to other marine invertebrates such as decapod crustaceans (Pengilly \& Watson 1994), but the efficacy and reliability of this procedure should be tested in each case. In pilot studies with local sea stars Asterias vulgaris $(\mathrm{n}=20)$ and Henricia sanguinolenta ( $\mathrm{n}=5)$, we observed $100 \%$ tag loss after $24 \mathrm{~h}$ for PIT tags injected into the coelomic cavity on the aboral side of an arm (5 to $10 \mathrm{~cm}$ arm length). This underscores the need for preliminary assessment of tag retention prior to experimental validation of tagging effects. For species or situations in which PIT tags are shown not to have a biologically meaningful effect 
on the process(es) of interest, this methodology provides a powerful, cost-effective means of tracking individuals, particularly when other tagging techniques are intractable.

Acknowledgements. We thank J. Lindley, D. Lyons, L. Sauchyn, S. Clemente, M. Saunders, A. Pinder and A. Chapman for diving assistance, J. Kelly and J. Jones for conducting the laboratory experiment, L. Sauchyn for conducting the $24 \mathrm{~h}$ feeding trial, and J. Lindley for assistance in constructing cages. The research was funded by a Discovery Grant and a Research Tools and Equipment Grant from the Natural Sciences and Engineering Research Council of Canada (NSERC) to R.E.S. J.S.L.G. was supported by a scholarship from NSERC.

\section{LITERATURE CITED}

Duggan RE, Miller RJ (2001) External and internal tags for the green sea urchin. J Exp Mar Biol Ecol 258:115-122

Dumont CP, Himmelman JH, Russell MP (2006) Daily movement of the sea urchin Strongylocentrotus droebachiensis in different subtidal habitats in eastern Canada. Mar Ecol Prog Ser 317:87-99

Gibbons JW, Andrews KM (2004) PIT tagging: simple technology at its best. Bioscience 54:447-454

Hagen NT (1996) Tagging sea urchins: a new technique for individual identification. Aquaculture 139:271-284

Kalbfleisch JD, Prentice RL (1980) Statistical analysis of failure time data. Wiley, New York

Kalvass PE, Hendrix JM, Law PM (1998) Experimental analysis of 3 internal marking methods for red sea urchins. Calif Fish Game 84:88-99

Kawamata S (1998) Effect of wave-induced oscillatory flow on grazing by a subtidal sea urchin Strongylocentrotus nudus (A-Agassiz). J Exp Mar Biol Ecol 224:31-48

Kobayashi S, Taki J (1969) Calcification in sea urchins. I. A tetracycline investigation of growth of the mature test in Strongylocentrotus intermedius. Calcif Tissue Res 4:

Editorial responsibility: Ricardo Cattaneo-Vietti, Genova, Italy
$210-223$

> Lauzon-Guay JS, Scheibling RE (2007a) Behaviour of sea urchin Strongylocentrotus droebachiensis grazing fronts: food-mediated aggregation and density-dependent facilitation. Mar Ecol Prog Ser 329:191-204

> Lauzon-Guay JS, Scheibling RE (2007b) Seasonal variation in movement, aggregation and destructive grazing of the green sea urchin (Strongylocentrotus droebachiensis) in relation to wave action and sea temperature. Mar Biol 151:2109-2118

Meidel SK, Scheibling RE (1998) Size and age structure of the sea urchin Strongylocentrotus droebachiensis in different habitats. In: Mooi R, Telford M (eds) Echinoderms. Balkema, Rotterdam, p 737-742

Pengilly D, Watson LJ (1994) Automated detection of internally injected tags in red king crabs at crab processing facilities. Fish Res 19:293-300

Percy JA (1973) Thermal adaptation in the boreo-arctic echinoid Strongylocentrotus droebachiensis (O. F. Muller, 1776). II. Seasonal acclimatization and urchin activity. Physiol Zool 46:129-136

Rogers-Bennett L, Rogers DW, Bennett WA, Ebert TA (2003) Modeling red sea urchin growth using six growth functions-Strongylocentrotus franciscanus. Fish Bull (Wash DC) 101:614-626

Russell MP, Ebert TA, Petraitis PS (1998) Field estimates of growth and mortality of the green sea urchin Strongylocentrotus droebachiensis. Ophelia 48:137-153

> Shelton AO, Woodby DA, Hebert K, Witman JD (2006) Evaluating age determination and spatial patterns of growth in red sea urchins in southeast Alaska. Trans Am Fish Soc 135:1670-1680

Winer BJ, Brown DR, Mitchels KM (1991) Statistical principles in experimental design, 3rd edn. McGraw-Hill, Boston

Woods CMC, James PJ (2005) Evaluation of passive integrated transponder tags for individually identifying the sea urchin Evechinus chloroticus (Valenciennes). Aquacult Res 36:730-732

Zar JH (1999) Biostatistical analysis. Prentice Hall, Engelwood Cliffs, NJ

Submitted: December 13, 2007; Accepted: February 23, 2008 Proofs received from author(s): April 6, 2008 